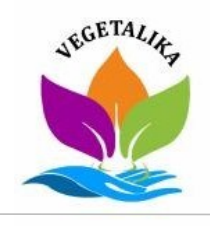

Vegetalika Vol. 10 No. 4, November 2021: 273-286

Available online at https://jurnal.ugm.ac.id/jbp

DOI: https://doi.org/10.22146/veg.62170

p-ISSN: 2302-4054 | e-ISSN: 2622-7452

\title{
Karakteristik Agroforestri Kebun Campuran di Kapanewon Patuk, Kabupaten Gunungkidul
}

\author{
Characteristic of Mixed Garden Agroforestry in Patuk District, \\ Gunungkidul Regency
}

\author{
Arifah Hidayati ${ }^{1}$, Priyono Suryanto ${ }^{1 *}$, Ronggo Sadono ${ }^{2)}$, Taufan Alam ${ }^{3)}$ \\ 1) Departemen Silvikultur, Fakultas Kehutanan, Universitas Gadjah Mada, Yogyakarta \\ Jalan Agro No.1, Bulaksumur, Kocoran, Caturtunggal, Depok, Sleman, \\ D.I. Yogyakarta 55281, Indonesia. \\ 2) Departemen Manajemen Hutan, Fakultas Kehutanan, Universitas Gadjah Mada, Yogyakarta \\ Jalan Agro No.1, Bulaksumur, Kocoran, Caturtunggal, Depok, Sleman, \\ D.I. Yogyakarta 55281, Indonesia. \\ 3) Departemen Budidaya Pertanian, Fakultas Pertanian, Universitas Gadjah Mada \\ Jalan Flora No. 1, Bulaksumur, Sleman, Yogyakarta 55281, Indonesia. \\ *) Penulis untuk korespodensi E-mail: psuryanto@ugm.ac.id
}

Diajukan: 11 Desember 2020 /Diterima: 19 Oktober 2021 /Dipublikasi: 26 November 2021

\begin{abstract}
Over the last few decades, agroforestry has been a solution to the lack of land availability in various regions in Indonesia, including in the Patuk District with a mixed garden pattern. This study aimed to determine the structure and composition of vegetation in mixed garden agroforestry. The study was conducted in Pathuk District, Gunungkidul Regency, Province of Yogyakarta, Indonesia on June-August 2020. The purposive sampling method was used to determine the samples, with three categories of land sizes, namely narrow $\left(<500 \mathrm{~m}^{2}\right)$, medium $\left(500-1000 \mathrm{~m}^{2}\right)$, and large $\left(>1000 \mathrm{~m}^{2}\right)$. Data were collected using the census method on all tree life stages then analyzed by calculating the Importance Value Index and Margalef Richness Index (R). Tree structures were visualized using Sexl-FS. Results showed that the mixed gardens agroforestry in the Patuk District were composed of wood-producing crops, Multipurpose Tree Species (MPTS), and annual crops. The mixed gardens in three land categories comprised 23, 25, and 21 tree species, respectively. Durian, mahogany, and rosewood dominated all land categories.
\end{abstract}

Keywords: agroforestry; Kapanewon Pathuk; mixed garden

\section{INTISARI}

Selama beberapa dekade terakhir, agroforestri menjadi solusi atas minimnya ketersediaan lahan di berbagai wilayah di Indonesia, termasuk di Kecamatan Patuk dengan pola kebun campur. Penelitian ini bertujuan untuk mengetahui struktur dan komposisi vegetasi pada agroforestri kebun campuran. Penelitian dilaksanakan di Kapanewon Pathuk, Kabupaten Gunungkidul, Provinsi Daerah Istimewa Yogyakarta, Indonesia pada bulan Juni-Agustus 2020. Pengambilan sampel dilakukan dengan metode purposive sampling dengan tiga kategori luas lahan yaitu sempit $\left(<500 \mathrm{~m}^{2}\right)$, sedang $\left(500-1000 \mathrm{~m}^{2}\right)$, dan besar $\left(>1000 \mathrm{~m}^{2}\right)$. 
Pengumpulan data dilakukan dengan metode sensus pada semua tahapan kehidupan pohon kemudian dianalisis dengan menghitung nilai indek penting (INP) dan Margalef Richness Index (R). Struktur pohon divisualisasikan menggunakan SexI-FS software. Hasil penelitian menunjukkan bahwa agroforestri kebun campuran di Kapanewon Patuk terdiri dari tanaman penghasil kayu, jenis pohon serbaguna, dan tanaman semusim. Kebun campuran di tiga kategori lahan masing-masing terdiri dari 23, 25, dan 21 jenis pohon. Durian, mahoni, dan sonokeling mendominasi semua kategori lahan.

\section{Kata Kunci: agroforestri; Kapanewon Pathuk; kebun campur}

\section{PENDAHULUAN}

Selama beberapa dekade terakhir, agroforestri mencakup komponen kehutanan, pertanian, dan peternakan telah dijadikan solusi atas minimnya ketersediaan lahan di dunia. Agroforestri merupakan suatu sistem buatan (man-made) aplikasi praktis interaksi manusia dengan sumberdaya alam di sekitarnya. Agroforestri dikembangkan untuk memecahkan permasalahan pemanfaatan lahan dan pengembangan pedesaan, serta pemanfaatan potensi maupun peluang untuk kesejahteraan manusia dengan dukungan kelestarian sumberdaya beserta lingkungannya (Yuwariah, 2015).

Agroforestri telah lama dikenal oleh masyarakat tradisional di Indonesia, salah satunya di Pulau Jawa dengan istilah tumpangsari atau mratani. Agroforestri ini dapat berupa hortikultura atau tegakan hutan di halaman rumah atau pekarangan. Bentuk agroforestri salah satunya di Kapanewon Patuk, Kabupaten Gunungkidul dengan pola kebun campuran. Kebun campuran merupakan salah satu bentuk agroforestri yang meniru ekosistem hutan tropis pada tingkat kesulitan yang rumit (Forrester 1968).
Martini et al. (2010) menyatakan bahwa sistem ini menjadi suatu pilihan bagi para petani dengan kepemilikan lahan yang sempit $(0,25-$ 2 hektar) karena dapat memegang banyak peranan seperti menjadi sumber pendapatan keluarga, sumber tanaman obat, menyediakan kayu sebagai bahan bakar, peralatan rumah tangga, serta peralatan kerja dari berbagai tanaman yang tumbuh di dalamnya.

Luas kepemilikan lahan oleh masyarakat sangat erat kaitannya dengan tingkat strata sosial dan kesejahteraannya. Semakin luas lahan yang dimiliki atau dikuasai oleh seseorang maka semakin tinggi strata sosial dan kesejahteraan orang bersangkutan. Hal ini juga berkaitan erat dengan pengambilan keputusan dan keleluasaan memilih jenis tanaman yang dapat dikembangkannya. Semakin luas lahan yang dimiliki maka semakin banyak pula jenis yang dapat dikembangkan (Millang, 2009). Agroforestri dikenal telah berkontribusi terhadap 9 dari total 17 poin dalam Sustainable Development Goals (SDGs) atau tujuan pembangunan bersama yang dicetuskan oleh Perserikatan Bangsa Bangsa (PBB) pada tahun 2015. Dampak yang paling dirasakan adalah implementasi pada 
poin pemberantasan kemiskinan (SDG 1), peniadaan kelaparan (SDG 2), penanganan perubahan iklim (SDG 13), dan kehidupan di darat (SDG 15). Selain itu praktik agroforestri juga menunjukkan kontribusi nyata terhadap usaha peningkatan kesetaraan gender atau pengurangan kesenjangan (SDG 10) (Tsioumani, 2018). Penelitian ini bertujuan untuk mengetahui struktur dan komposisi vegetasi pada agroforestri kebun campuran. Hasil dari penelitian ini dapat dijadikan contoh pengelolaan kebun campuran yang berkelanjutan sehingga berkontribusi terhadap SDGs.

\section{BAHAN DAN METODE}

Penelitian dilakukan pada lahan agroforestri kebun campuran di Kapanewon Patuk, Kabupaten Gunungkidul, Provinsi Daerah Istimewa Yogyakarta. Wilayah ini terletak pada ketinggian 200-700 m dpl dengan curah hujan tahunan $2300 \mathrm{~mm}$. Kalurahan Patuk memiliki luas 291 ha, keadaannya berbukit-bukit, jenis tanah didominasi latosol dengan batuan induk vulkanik. Sebagian besar petani di desa ini menanami tegalan dan pekarangan mereka dengan jenis Multipurpose Tree Species (MPTS) seperti kakao, durian, kelapa, melinjo, dan sebagainya.

Pengambilan data dilakukan secara purposive sampling dengan membuat petak ukur bertingkat (nested sampling). Variabel yang diamati untuk analisis vegetasi yaitu jenis pohon, tinggi pohon, tinggi batang bebas cabang (tbbc), diameter, lebar tajuk, dan titik koordinat pohon di lapangan. Selain itu perlu dilakukan pengambilan data lingkungan, meliputi suhu dan kelembapan udara, intensitas cahaya, dan curah hujan. Data sosial mengenai analisis gender diambil melalui wawancara dengan responden yang memiliki lahan dengan tipe penggunaan agroforestri kebun campuran. Ratnaputri (2011) menyatakan bahwa variabel yang dibutuhkan yaitu: 1) Data identitas responden, yaitu: nama, umur, pendidikan, jenis kelamin, pekerjaan., 2) Informasi sosial ekonomi meliputi: luas kepemilikan lahan, kepemilikan ternak., 3) Data tentang pengambilan keputusan dalam kegiatan agroforestry yang meliputi pemilihan jenis vegetasi dan penentuan pemanfaatan hasil panen., 4) Data tentang peran dan aktivitas kerja yang meliputi pembagian kerja dan keikutsertaan laki-laki dan perempuan.

Komposisi jenis penyusun vegetasi yang dominan dengan pendekatan Indeks Nilai Penting (INP) jenis tersebut. Analisis keragaman jenis kekayaan vegetasi pada agroforestri tipe kebun campuran menggunakan pendekatan Indeks Margalef (R). Proyeksi diagram profil pohon secara vertikal dan horizontal dilakukan menggunakan Sexl-FS software dengan variabel yang diolah meliputi tinggi pohon, tinggi batang bebas cabang (tbbc), lebar tajuk pada empat arah mata angin (U, T, S, B), dan titik koordinat pohon. 


\section{HASIL DAN PEMBAHASAN}

Kebun campuran di Kapanewon Patuk didominasi oleh kombinasi antara jenis tanaman kayu, MPTS, dan tanaman pertanian atau semusim. Jenis penghasil kayu yang ditemui antara lain adalah mahoni (Swietenia mahagony), sengon (Paraserianthes falcataria), jati (Tectona grandis), dan sonokeling (Dalbergia latifolia). Jenis MPTS didominasi dengan tanaman buah-buahan yaitu durian (Durio zibethinus), kakao (Theobroma cacao), sirsak (Annona muricata), petai (Parkia speciosa), jengkol (Archidendron pauciflorum), melinjo (Gnetum gnemon), dan alpukat (Persea americana). Tanaman pertanian yang banyak dibudidayakan di bawah tegakan antara lain yaitu pisang (Musa paradisiaca), pepaya (Carica papaya), singkong (Manihot utilissima), ubi jalar (Ipomoea batatas), nanas (Ananas comosus), serai (Cymbopogon citratus), dan lengkuas (Alpinia galanga). Jenis vegetasi yang ditemui sebagian besar merupakan jenis yang sengaja ditanam oleh pemilik lahan, namun dalam beberapa kasus juga ditemui hasil permudaan alam.

Berdasarkan hasil analisis vegetasi dengan menggunakan Indeks Margalef (R), dapat diketahui bahwa kekayaan jenis penyusun pada tiap tingkatan hidup tanaman di ketiga kategori luasan lahan memiliki tren yang cenderung berbeda (Gambar 1). Pada tingkatan semai, nilai $\mathrm{R}$ tertinggi ada pada kategori luasan lahan sedang $\left(500-1000 \mathrm{~m}^{2}\right)$ yaitu sebesar 2,42. Pada tingkatan pancang, kekayaan jenis penyusun agroforestri memiliki tren semakin meningkat dengan nilai $R$ tertinggi sebesar 3,28 pada luasan lahan besar (> $1000 \mathrm{~m}^{2}$ ). Pada tingkatan tiang, nilai $R$ terbesar yaitu 3,87 pada kategori luasan lahan kecil $\left(<500 \mathrm{~m}^{2}\right)$, sedangkan $R$ tertinggi untuk tingkatan pohon adalah 3,17 pada kategori luasan lahan sedang (Gambar 1).

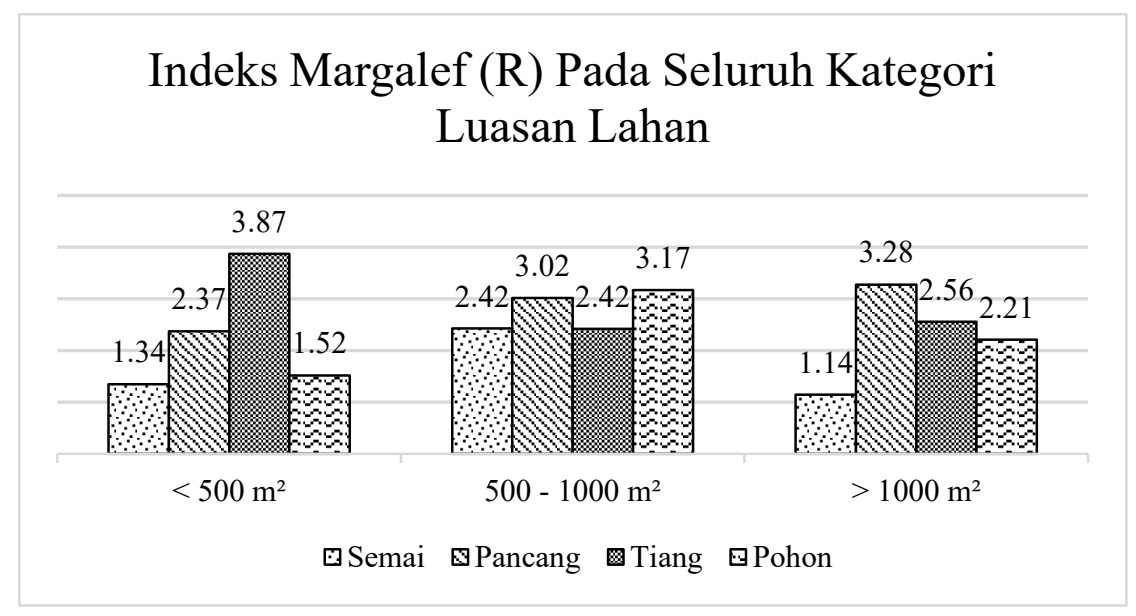

Gambar 1. Nilai Indeks Margalef (R) pada seluruh kategori luasan lahan 
Pada ketiga kategori luasan lahan terdapat perbedaan jumlah spesies (Tabel 1). Di kelima plot pengamatan untuk kategori luasan lahan kecil $\left(<500 \mathrm{~m}^{2}\right)$, ada 23 jenis tanaman dengan 5 jenis tanaman penghasil kayu dan 18 tanaman MPTS. Pada kategori luasan lahan sedang $\left(500-1000 \mathrm{~m}^{2}\right)$, ada 25 jenis vegetasi penyusun dengan 7 jenis diantaranya adalah tanaman penghasil kayu dan sisanya adalah jenis MPTS. Sedangkan di kategori luasan lahan besar $\left(>1000 \mathrm{~m}^{2}\right)$ jenis yang ditemui paling sedikit yaitu 21 jenis tanaman dengan rinciannya adalah 4 tanaman penghasil kayu dan 17 jenis MPTS.

Tabel 1. Komposisi jenis lahan agroforestri kebun campuran

\begin{tabular}{lcccc}
\hline \multirow{2}{*}{ Komposisi vegetasi penyusun } & \multicolumn{3}{c}{ Kategori luasan lahan } \\
\cline { 2 - 5 } & $<500 \mathrm{~m}^{2}$ & $500-1000 \mathrm{~m}^{2}$ & $>1000 \mathrm{~m}^{2}$ \\
\hline \multicolumn{2}{c}{ Tanaman kayu } & 5 & 7 & 4 \\
Multipurpose Tree Species & 18 & 18 & 17 \\
\hline \multirow{3}{*}{ Rata-rata N/ha } & Semai & 1717,57 & 1428,69 & 535,45 \\
& Pancang & 506,94 & 310,81 & 115,03 \\
& Tiang & 216,70 & 120,16 & 48,45 \\
& Pohon & 119,47 & 130,01 & 65,41 \\
\hline
\end{tabular}

Dominansi suatu spesies bisa disebabkan karena kemampuan adaptasi dan regenerasinya bagus, namun dalam praktik agroforestri hal ini bukan faktor penentu satusatunya. Menurut Suryanto et al. (2005), berdasarkan struktur dan komponen serta sejarah pengelolaannya agroforestri dapat dibagi menjadi tiga jenis yaitu agroforestri tahap awal, tengah, dan lanjut. Agroforestri kebun campuran merupakan agroforestri tahap awal karena lahannya masih dikelola secara intensif, sehingga perlakuan pemeliharaan oleh pemilik lahan merupakan faktor yang memiliki pengaruh besar terhadap dominansi suatu jenis.
Pemilik lahan yang menerapkan agroforestri kebun campuran di Kalurahan Patuk umumnya tidak memiliki perencanaan yang mendetail sebelum melakukan penanaman. Jenis yang paling banyak dibudidayakan adalah jenis yang bernilai jual tinggi dan cenderung tidak membutuhkan perawatan yang intensif.

Selain itu, ketersediaan bibit juga merupakan faktor yang berpengaruh. Semai yang ditanam biasanya didapatkan dari hasil pembibitan swadaya, anakan atau trubusan, maupun hasil membeli dari pedagang bibit. Selain itu pada beberapa waktu tertentu terdapat bantuan bibit dari pemerintah yang disalurkan melalui kelompok tani. 
Tabel 2. Indeks Nilai Penting pada Kategori Luasan Lahan $<500 \mathrm{~m}^{2}$

\begin{tabular}{|c|c|c|c|c|c|c|}
\hline \multirow{2}{*}{ No } & \multirow{2}{*}{ Spesies } & \multirow{2}{*}{ Nama ilmiah } & \multicolumn{4}{|c|}{ Indeks Nilai Penting (\%) } \\
\hline & & & Semai & Pancang & Tiang & Pohon \\
\hline 1 & Alpukat & Persea americana & 0 & 0 & 9.185 & 0 \\
\hline 2 & Cengkeh & Syzygium aromaticum & 0 & 0 & 7.578 & 0 \\
\hline 3 & Dadap & Erythrina variegata & 0 & 0 & 6.757 & 0 \\
\hline 4 & Durian & Durio zibethinus & 16.831 & 22.858 & 51.500 & 149.243 \\
\hline 5 & Jambu air & Syzygium aqueum & 0 & 5.071 & 0 & 0 \\
\hline 6 & Jati & Tectona grandis & 0 & 0 & 17.255 & 0 \\
\hline 7 & Jengkol & Archidendron pauciflorum & 0 & 0 & 19.058 & 11.656 \\
\hline 8 & Jeruk nipis & Citrus aurantiifolia & 0 & 0 & 7.307 & 0 \\
\hline 9 & Jeruk purut & Citrus hystrix & 5.524 & 4.889 & 7.307 & 0 \\
\hline 10 & Kakao & Theobroma cacao & 0 & 67.314 & 42.040 & 0 \\
\hline 11 & Kelapa & Cocos nucifera & 0 & 0 & 9.079 & 0 \\
\hline 12 & Mahoni & Swietenia mahagony & 41.420 & 76.630 & 62.733 & 57.150 \\
\hline 13 & Mangga & Mangifera indica & 5.524 & 5.860 & 0 & 0 \\
\hline 14 & Melinjo & Gnetum gnemon & 5.784 & 20.096 & 0 & 0 \\
\hline 15 & Mengkudu & Morinda citrifolia & 0 & 0 & 7.651 & 0 \\
\hline 16 & Nangka & Artocarpus heterophyllus & 0 & 0 & 8.773 & 0 \\
\hline 17 & Petai & Parkia speciosa & 0 & 13.495 & 7.438 & 24.243 \\
\hline 18 & Rambutan & Nephelium lappaceum & 0 & 0 & 7.651 & 0 \\
\hline 19 & Sawo & Manilkara kauki & 0 & 7.864 & 9.402 & 0 \\
\hline 20 & Sengon & Paraserianthes falcataria & 0 & 0 & 0 & 21.823 \\
\hline 21 & Sirsak & Annona muricata & 8.649 & 15.113 & 11.805 & 0 \\
\hline 22 & Sonokeling & Dalbergia latifolia & 100.795 & 54.054 & 21.543 & 0 \\
\hline 23 & Waru & Hibiscus tiliaceus & 5.524 & 0 & 0 & 0 \\
\hline
\end{tabular}

Jenis yang ditemukan pada seluruh tingkatan hidup adalah durian, kakao, mahoni, dan sonokeling (Tabel 3). Durian Patuk memiliki peluang yang menjanjikan di pasaran, karena dikenal dengan kualitas buahnya yang bagus dan dipanen saat sudah benar-benar matang (masak pohon) yaitu ketika buah sudah jatuh dari pohonnya. Pada awal tahun 2000, sudah ada warga Kalurahan Patuk yang menekuni budidaya durian meskipun hanya ditanam di lahan pekarangan yang terbatas, tetapi berbagai varietas durian mulai banyak dibudidayakan pada tahun 2010 setelah beberapa warga di wilayah ini yang berhasil memanen buah dengan kualitas yang bagus sehingga durian lokal Patuk banyak dicari oleh pembeli dari dalam maupun luar Daerah Istimewa Yogyakarta. Sejak tahun 2014 dilaksanakan 'Festival Durian' di Gogor Park untuk mempromosikan hasil durian lokal Kapanewon Patuk dengan varietas yang beragam seperti durian kencana rukmi, petruk, dan montong. 
Tabel 3. Indeks Nilai Penting pada Kategori Luasan Lahan $500-1000 \mathrm{~m}^{2}$

\begin{tabular}{|c|c|c|c|c|c|c|}
\hline \multirow{2}{*}{ No } & \multirow{2}{*}{ Spesies } & \multirow{2}{*}{ Nama ilmiah } & \multicolumn{4}{|c|}{ Indeks Nilai Penting (\%) } \\
\hline & & & Semai & Pancang & Tiang & Pohon \\
\hline 1 & Alpukat & Persea americana & 3.348 & 10.215 & 0 & 8.240 \\
\hline 2 & Dadap & Erythrina variegata & 0 & 5.2948 & 0 & 0 \\
\hline 3 & Durian & Durio zibethinus & 14.689 & 48.661 & 57.863 & 85.247 \\
\hline 4 & Jambu air & Syzygium aqueum & 3.348 & 5.115 & 0 & 0 \\
\hline 5 & Jambu biji & Psidium guajava & 3.978 & 6.381 & 0 & 0 \\
\hline 6 & Jati & Tectona grandis & 0 & 6.438 & 28.555 & 16.780 \\
\hline 7 & Jengkol & Archidendron pauciflorum & 0 & 9.950 & 0 & 9.453 \\
\hline 8 & Jeruk manis & Citrus sinensis & 0 & 4.899 & 0 & 0 \\
\hline 9 & Johar & Senna siamea & 3.287 & 0 & 0 & 0 \\
\hline 10 & Kakao & Theobroma cacao & 3.476 & 92.561 & 46.947 & 7.702 \\
\hline 11 & Kelapa & Cocos nucifera & 0 & 0 & 0 & 41.037 \\
\hline 12 & Kelengkeng & Dimocarpus longan & 0 & 5.003 & 0 & 0 \\
\hline 13 & Lamtoro & Leucaena leucocephala & 3.531 & 4.555 & 0 & 0 \\
\hline 14 & Mahoni & Swietenia mahagony & 100.581 & 28.193 & 48.280 & 64.439 \\
\hline 15 & Mangga & Mangifera indica & 13.392 & 0 & 0 & 0 \\
\hline 16 & Melinjo & Gnetum gnemon & 4.228 & 0 & 19.211 & 7.731 \\
\hline 17 & Mimba & Azidarachta indica & 0 & 0 & 0 & 7.591 \\
\hline 18 & Nangka & Artocarpus heterophyllus & 3.531 & 6.008 & 0 & 0 \\
\hline 19 & Petai & Parkia speciosa & 0 & 0 & 20.911 & 8.764 \\
\hline 20 & Rambutan & Nephelium lappaceum & 0 & 0 & 23.478 & 7.618 \\
\hline 21 & Salam & Syzygium polyanthum & 3.727 & 0 & 0 & 0 \\
\hline 22 & Sengon & Paraserianthes falcataria & 3.715 & 0 & 32.242 & 11.414 \\
\hline 23 & Sirsak & Annona muricata & 10.429 & 36.609 & 9.992 & 0 \\
\hline 24 & Sonokeling & Dalbergia latifolia & 21.262 & 30.116 & 12.521 & 23.984 \\
\hline 25 & Waru & Hibiscus tiliaceus & 3.476 & 0 & 0 & 0 \\
\hline
\end{tabular}

Pada kategori luasan lahan besar, jenis yang memiliki tingkatan hidup yang lengkap yaitu durian, mahoni, dan sengon. INP tertinggi pada tingkatan semai dimiliki oleh sonokeling. Sedangkan pada tingkat pancang, tiang, dan pohon didominasi oleh durian. Meskipun semai sonokeling mendominasi dengan INP sebesar 118,954\% tetapi terdapat kekosongan pada tingkat hidup pohon. Hal ini dikarenakan para pemilik lahan sudah memanen pohon sonokeling pada kisaran tahun 2018-2019 dan baru mulai gencar menanam kembali jenis ini pada tahun 2020.
Struktur tegakan pada kategori luasan lahan sempit $\left(<500 \mathrm{~m}^{2}\right)$ terdiri dari lima stratum yaitu stratum A, B, C, D, dan E (Gambar 2). Pada stratum A ditemukan tiga spesies dengan jumlah masing-masing satu individu, yaitu spesies durian, jati, dan sengon. Individu pohon tertinggi yang ditemukan pada stratum $A$ adalah pohon jati setinggi $35 \mathrm{~m}$. Pohon jati ini sebenarnya sudah dapat dipanen tetapi pemilik lahan belum menebang pohon tersebut karena menunggu hingga ada kebutuhan mendesak yang membutuhkan dana besar 
Tabel 4. Indeks Nilai Penting pada Kategori Luasan Lahan $>1000 \mathrm{~m}^{2}$

\begin{tabular}{|c|c|c|c|c|c|c|}
\hline \multirow{2}{*}{ No } & \multirow{2}{*}{ Spesies } & \multirow{2}{*}{ Nama ilmiah } & \multicolumn{4}{|c|}{ Indeks Nilai Penting (\%) } \\
\hline & & & Semai & Pancang & Tiang & Pohon \\
\hline 1 & Alpukat & Persea americana & 7.625 & 8.827 & 0 & 9.361 \\
\hline 2 & Cengkeh & Syzygium aromaticum & 0 & 10.058 & 20.565 & 0 \\
\hline 3 & Durian & Durio zibethinus & 12.636 & 65.864 & 81.820 & 167.833 \\
\hline 4 & Jambu air & Syzygium aqueum & 0 & 12.582 & 0 & 0 \\
\hline 5 & Jambu biji & Psidium guajava & 0 & 8.017 & 0 & 0 \\
\hline 6 & Jarak merah & Jatropha gossypifolia & 5.521 & 0 & 0 & 0 \\
\hline 7 & Jati & Tectona grandis & 6.754 & 6.303 & 10.189 & 0 \\
\hline 8 & Jeruk manis & Citrus sinensis & 0 & 11.631 & 10.855 & 9.233 \\
\hline 9 & Kakao & Theobroma cacao & 6.318 & 60.340 & 30.157 & 0 \\
\hline 10 & Kaliandra & Calliandra sp. & 0 & 8.567 & 0 & 0 \\
\hline 11 & Kelapa & Cocos nucifera & 0 & 0 & 0 & 9.384 \\
\hline 12 & Kenanga & Cananga odorata & 0 & 6.002 & 0 & 0 \\
\hline 13 & Mahoni & Swietenia mahagony & 29.194 & 43.022 & 78.492 & 37.087 \\
\hline 14 & Melinjo & Gnetum gnemon & 0 & 6.440 & 0 & 11.202 \\
\hline 15 & Nangka & Artocarpus heterophyllus & 12.418 & 0 & 9.812 & 0 \\
\hline 16 & Petai & Parkia speciosa & 0 & 5.610 & 9.105 & 9.105 \\
\hline 17 & Rambutan & Nephelium lappaceum & 0 & 0 & 11.390 & 15.125 \\
\hline 18 & Sengon & Paraserianthes falcataria & 6.100 & 6.742 & 18.346 & 22.577 \\
\hline 19 & Sirsak & Annona muricata & 0 & 0 & 0 & 9.094 \\
\hline 20 & Sonokeling & Dalbergia latifolia & 118.954 & 34.473 & 9.658 & 0 \\
\hline
\end{tabular}

Stratum B diisi oleh empat spesies yaitu durian, jati, mahoni, dan petai. Durian mendominasi pada lapisan ini dengan jumlah individu sebanyak 6 pohon. Pada stratum C ditemukan sebanyak 16 jenis pohon yang mayoritas adalah tanaman MPTS. Jenis yang mendominasi adalah durian dan mahoni dengan masing-masing jumlah individu sebanyak 16 pohon. Selain itu jenis lain seperti kakao, jati, jengkol, dan sonokeling juga banyak ditemui. Jenis pohon buah seperti alpukat, nangka, rambutan, sawo, dan sirsak umumnya menempati stratum C. Hal ini disebabkan karena biasanya dilakukan pemangkasan cabang atau pucuk pohon dan petani menyisakan percabangan yang masih relatif rendah sehingga lebih mudah untuk melakukan pemanenan buah.

Pada kategori luasan ini juga terdapat stratum D yang terdiri dari kakao, dan beberapa tanaman semusim seperti pisang dan singkong. Pohon kakao secara rutin dipangkas setiap bulan oleh para petani karena apabila percabangannya terlalu banyak maka tajuknya makin rimbun dan lebih mudah terserang hama dan penyakit. Pohon kakao yang ditemukan di lapangan mayoritas tingginya berkisar antara 3-10 m. Stratum $E$ atau lapisan paling bawah tersusun atas tanaman semusim yaitu ubi jalar, nanas, dan berbaga jenis emponempon seperti serai, jahe, serta lengkuas. 


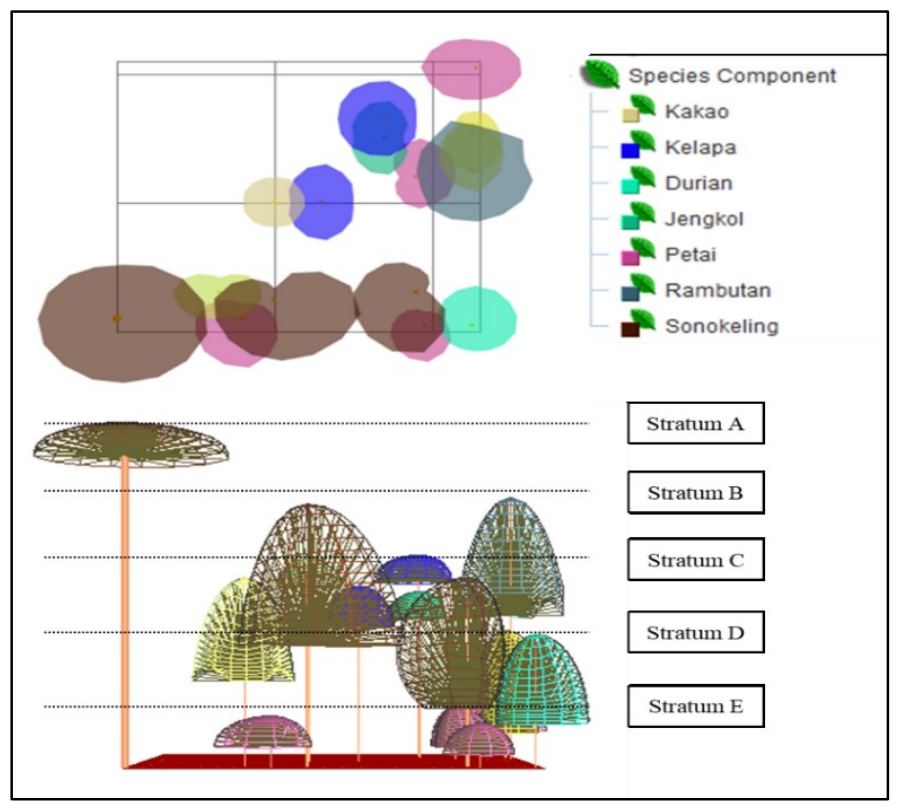

Gambar 2. Struktur horizontal dan vertikal pada luasan lahan $<500 \mathrm{~m}^{2}$

Berdasarkan hasil proyeksi horizontal dengan software SexI-FS dapat dilihat bahwa pola penanaman jenis tanaman kehutanan tidak merata. Mayoritas pemilik lahan belum menerapkan jarak tanam yang teratur sehingga pola persebarannya ada yang acak dan juga mengelompok di satu titik tertentu. Namun pemilik lahan tidak menanam jenis dengan tajuk yang terlalu lebar agar bidang olah untuk tanaman pertanian tetap mendapatkan cahaya matahari dengan intensitas cukup tinggi.

Struktur tegakan pada kategori luasan lahan sedang $\left(500-1000 \mathrm{~m}^{2}\right)$ secara vertikal terdiri dari empat stratum yaitu $B, C, D$, dan $E$ (Gambar 3). Stratum B diisi oleh empat jenis MPTS penghasil buah dan empat jenis tanaman kayu. MPTS yang ditemui adalah durian, jengkol, kakao, dan kelapa, sedangkan jenis penghasil kayu adalah jati, mahoni, sengon, dan sonokeling.

Stratum C terdiri dari 13 jenis tanaman, yaitu 8 jenis pohon MPTS penghasil buah dan empat jenis tanaman kayu. Jenis MPTS pada stratum C adalah alpukat, durian, kakao, kelapa, melinjo, petai, rambutan, dan sirsak. Jenis penghasil kayu pada stratum ini adalah jati, mimba, sengon, dan sonokeling. Mahoni mendominasi stratum C. Stratum D hanya terdiri dari jenis kakao dan beberapa tanaman pertanian yaitu singkong, pisang, dan pepaya. Pada stratum E diisi oleh tanaman pertanian seperti ubi jalar, nanas, dan jenis empon-empon. 


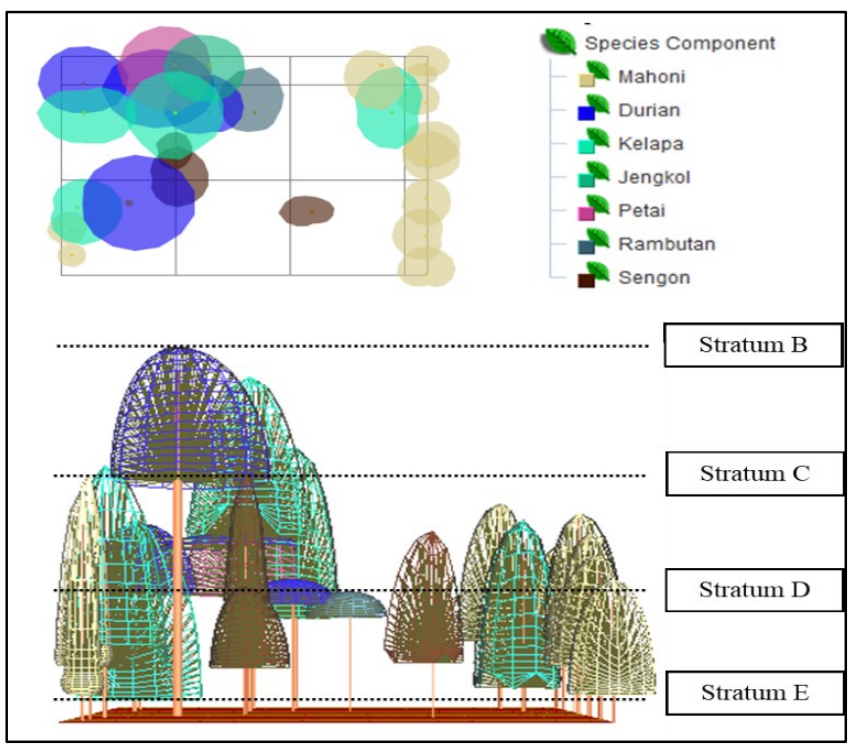

Gambar 3. Struktur horizontal dan vertikal pada luasan lahan $500-1000 \mathrm{~m}^{2}$

Hasil proyeksi vertikal menunjukkan bahwa pada kategori luasan lahan besar (> $1000 \mathrm{~m}^{2}$ ) terbagi menjadi empat stratum yaitu B, C, D, dan E (Gambar 4). Stratum B hanya diisi oleh jenis durian. Stratum $C$ terdiri dari 15 jenis namun paling banyak ditemukan jenis durian dan mahoni dengan masing-masing jumlah individu sebanyak 48 dan 23 individu.
Stratum D tersusun atas empat jenis MPTS, yaitu durian, jeruk manis, kakao, dan rambutan. Pada lapisan ini juga ditemui jenis tanaman pertanian seperti singkong, pisang, dan pepaya. Stratum E atau lapisan paling bawah diisi oleh ubi jalar, nanas, serta jenis empon-empon.

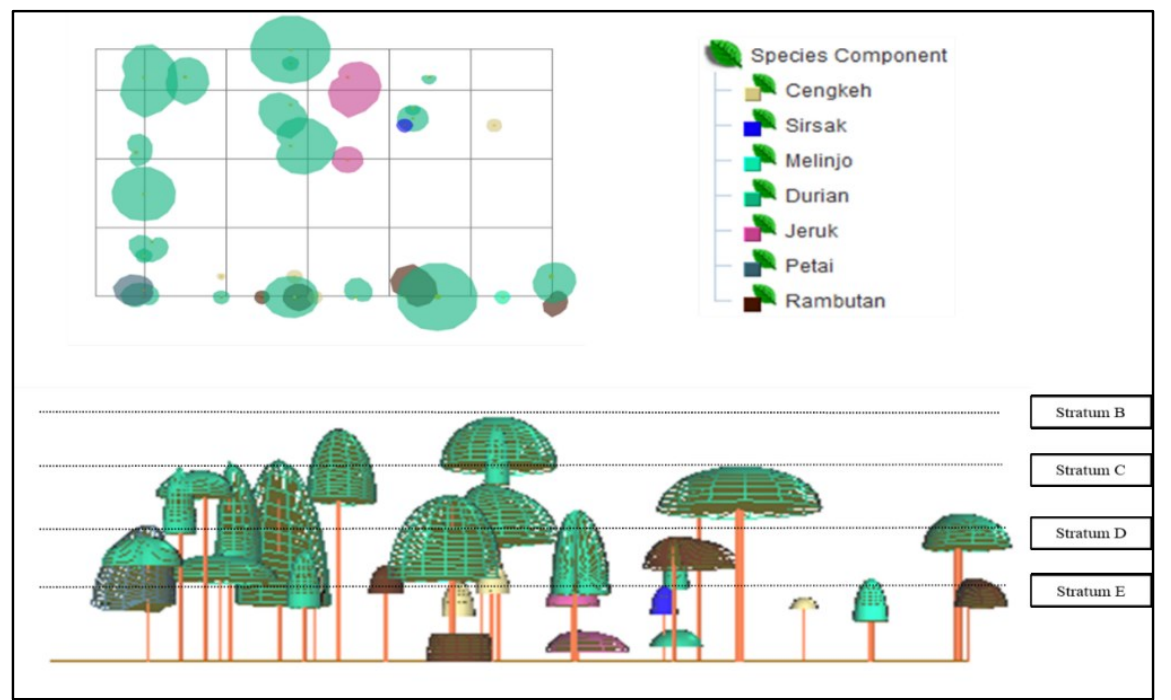

Gambar 4. Struktur horizontal dan vertikal pada luasan lahan $>1000 \mathrm{~m}^{2}$ 
Susunan vegetasi yang melimpah mengindikasikan bahwa lahan agroforestri kebun campuran di Kalurahan Patuk dapat menghasilkan manfaat sepanjang tahun dengan jenis produk yang beragam. Terdapat berbagai jenis hasil hutan kayu dan non-kayu yang dapat dipanen dalam jangka waktu bervariasi yaitu produk harian, mingguan, bulanan, dan tahunan.

\section{KESIMPULAN}

Kategori luasan lahan kecil, sedang, dan besar masing-masing ditemukan sebanyak 23, 25, dan 21 spesies yang didominasi oleh durian, mahoni, dan sonokeling. Jenis tanaman pertanian yang ditemui adalah pisang (Musa paradisiaca), pepaya (Carica papaya), singkong (Manihot utilissima), ubi jalar (Ipomoea batatas), nanas (Ananas comosus), serai (Cymbopogon citratus), dan lengkuas (Alpinia galanga). Struktur tegakan pada kategori luasan lahan kecil terdiri dari lima stratum yaitu stratum A, B, $C, D$, dan $E$, sedangkan pada kategori luasan lahan sedang dan besar tidak ditemui stratum $\mathrm{A}$.

\section{DAFTAR PUSTAKA}

Carlowitz, P.G. von. 1987. ICRAF's Multipurpose Tree and Shrub Information System. Agroforestry Systems, 5: 319338.

Chao, S. 2012. Forest Peoples: Numbers Across the World. Forest Peoples Programme. Moreton-in-Marsh. United Kingdom.

FAO. 2017. Agroforestry for landscape restoration: Exploring the potential of agroforestry to enhance the sustainability and resilienceof degraded landscapes.

Rome. https://doi.org/10.4060/i7374e.

Foroughbackh, R., Pinero, J.H., Alvarado, M.A., Avila, L.C. 2009. Use of Multipurpose Trees and Shrubs in Forestry and Agroforestry Systems in Northeastern Mexico. In: Handbook on Agroforestry: Management Practices and Environmental Impact. Nova Science Publishers. New York, USA.

Gold, M.A., Garrett, H.E. 2009. Agroforestry Nomenclature, Concepts, and Practices. In: Garrett, H.E. (Ed.), North American agroforestry: An integrated science and practice, seconded. Madison, WI: American Society of Agronomy: 45-56.

Hardja, D., Gregoire, V. 2008. SExI - FS: User Guide and Software version 2.1.0. world Agroforestry Centre and Institut de Recherche Pour Le Developpement (IRD).

IAASTD. 2008. Agriculture at A Crossroads: Global Report. International Assessment of Agricultural Knowledge, Science, and Technology for Development. Washington DC.

Khotimah, Y.K., Supardi, S., Antriyandarti, E. 2019. Pemanfaatn Sumber Daya Pertanian Lahan Kering di Pegunungan Karst Gunungkidul. Prosiding Seminar Nasional Fakultas Pertanian UNS, 3(1): 50-57 
Kumar, V. 2016. Multifunctional Agroforestry Systems in Tropics Region. Nature Environment and Pollution Technology, 15(2): 365-376.

Latue, Y.A., Pattinama, M.J., Lawalata, M. 2018. Sistem pengelolaan agroforestri di negeri riring kecamatan taniwel kabupaten seram bagian barat. Jurnal Agribisnis Kepulauan, 6(3): 212-230.

Luedeling, E., Kindt, R., Huth, N. And Koenig, K. 2014. Agroforestry systems in a changing climate-challenges in projecting future performance. Current Opinion in Environmental Sustainability, 6: 1-7.

Lundgren, B.O., Raintree, J.B. 1982. Sustained agroforestry. In Nestel, B., ed. Agricultural research for development: potentials and challenges in Asia, pp. 37-49. ISNAR. The Hague, the Netherlands.

Martini, E., Tata, H.L., Mulyoutami, E., Tarigan, J., Rahayu, S. 2010. Membangun Kebun Campuran: Belajar dari Kebun Pocal di Tapanuli dan Lampoeh di Tripa. World Agroforestry Cntre-ICRAF, SEA Regional Office. Bogor.

Protected Areas: The Role of Traditional Ecosystems, 90-106. IUCN, Gland, Switzerland dan Cambridge. United Kingdom.

Millang, S. 2009. Struktur dan Komposisi Jenis Agroforestry Kebun-Campuran pada
Berbagai Luas Pemilikan Lahan Di Desa Pattalikang Kecamatan Manuju Kabupaten Gowa. Biocelebes, 3(2): 6473.

Miller, DC, Ordoñez, PJ, Brown, SE, et al. 2019. The impacts of agroforestry on agricultural productivity, ecosystem services, and human well-being in low and middle income countries: an evidence and gap map. Campbell Systematic Reviews, 16(1): 16-18.

Mulyoutami, E., Martini, E., Khususiyah, N., Isnurdiansyah, Suyanto. 2012. Agroforestry and Forestry in Sulawesi Series: Gender, Livelihoods and Land in South and Southeast Sulawesi. ICRAF Working Paper no. 158.

Nair, P.K.R., Nair, V.D., Kumar, B.M. and Showalter, J.M. 2010. Carbon Sequestration in Agroforestry Systems. Adv. Agron., 108: 237-307.

Suryanto, P., Tohari, Sabarnudin, S.M. 2005. Dinamika Sistem Berbagi Sumber Daya (Resource Sharing) dalam Agroforestri: Dasar Pertimbangan Penyusunan Strategi Silvikultur. Ilmu Pertanian, 12(2): 165-178.

Suryanto, P., S.M. Widyastuti and J. Sartohadi. 2012. Traditional Knowledge of Homegarden-Dry Field Agroforestry as a Tool for Revitalization Management of Smallholder Land Use in Kulonprogo, Java, Indonesia. International Journal of Biology, 4(2): 173-183.

Vegetalika | https://doi.org/10.22146/veg.62170 
Suyanto. 2016. Agroforestry and Forestry in Sulawesi series: Women's participation in agroforestry: more benefit or burden? A gendered analysis of Gorontalo Province. Working Paper 226. World Agroforestry Centre (ICRAF) Southeast Asia Regional Program. Bogor, Indonesia.

Thaman, R.R., Elevitch, C.R., Wilkinson, K.M. 2000. Multipurpose Trees for Agroforestry in the Pacific Islands. Agroforestry Guides for Pacific Islands \#2. Permanent Agriculture Resources, Holualoa, Hawaii, USA.

Tilman, D., Cassman, K.G., Matson, P.A., Naylor, R., Polasky, S. 2002. Agricultural sustainability and intensive production practices. Nature, 418: 671-677.

Triwanto, J., Syarifudin, A., dan Mutaqin, T. 2012. Aplikasi Agroforestry di Desa Mentaraman Kecamatan Donomulyo Kabupaten Malang. DEDIKASI, Vol 9.

Udawatta, R.P., Rankoth, L.M. \& Jose, S. 2019. Agroforestry and Biodiversity. Sustainabilit, 11 (10): 2879.

Vergara, N.T. 1982. New Direction in Agroforestry; The Potential of Tropical Legume Trees, Improving Agroforestry in the Asia Pasific Tropics. Prepared by a Working Group on Agroforestry Environment and Policy Institute East West Center. Honolulu, Hawai.
Villamor, G.B., Akiefnawati, R., Van Noordwijk, M. DesrianT=tl, F., Pradhan, U. 2015a. Land Use Change and Shifts in Gender Roles in Central Sumatra, Indonesia. International Forestry Review. 17(4): 6175.

Villamor, G. B., Afiavi Dah-gbeto, P., Bell, A., Pradhan, U., \& van Noordwijk, M. 2015b. Gender-Specific Spatial Perspectives and Scenario Building Approaches for Understanding Gender Equity and Sustainability in Climate-Smart Landscapes. In Minang, P. A., van Noordwijk, M., Freeman, O. E., Mbow, C., de Leeuw, J., \& Catacutan, D. (Eds.) Climate-Smart Landscapes: Multifunctionality in Practice, 211-225. World Agroforestry Centre (ICRAF). Nairobi, Kenya.

Whitten, T., Soeriaatmadja, R.E., Afiff, S.A. 1996. The Ecology of Indonesian Series Volume II: The Ecology of Java and Bali. Periplus Editions (HK) Ltd. Singapore.

Widiarti, A., Prajadinata, S. 2008. Karakteristik Hutan Rakyat Pola Kebun Campuran. Jurnal Penelitian Hutan dan Konsevasi Alam, 2 (2)

World Agroforestry Centre. 2008. Transforming Lives and Landscapes. Strategy 20082015. World Agroforestry Centre. Nairobi, Kenya. 51 pp.

World Bank. 2004. Sustaining Forests: A Development Strategy. Washington DC. 
Zomer, R.J., Trabucco, A., Coe, R., Place, F., van Noordwijk, M. \& Xu, J.C. 2014. Trees on Farms: An Update and Reanalysis of Agroforestry's Global Extent and Socio-
Ecological Characteristics. Working Paper 179. World Agroforestry Centre (ICRAF) Southeast Asia Regional Program. Bogor, Indonesia. 